\title{
Main Aspects of Economic Freedom and Its Impact on Rising Living Standards
}

\author{
Vakhtang Chkareuli
}

\begin{abstract}
One of the basic human needs that plays a central role in social progress is freedom. Human development mostly means to expand choices. When we are forced to do things or not to do, we do not have that many choices. We are not allowed to make our own decisions.

Nowadays, economic freedom has become a broad term of discussions between economists (and not only).

Economic freedom is the most essential route to greater opportunities and good standards of living for all in any society. We cannot overemphasize the importance of economic freedom. It influences almost all aspects of a human's life and the environment where he/she lives.

People define economic freedom in many different ways, but still, what is economic freedom and why do we need to be economically free? In this paper we will discuss main aspects of economic freedom and its impact on rising living standards.
\end{abstract}

Index Terms-Economic freedom, government, living standards, GDP, growth.

\section{INTRODUCTION}

Generally, freedom is the state of being "unimprisoned" or "unenslaved" or "uncoerced". But still, there can be as many definitions to "freedom" as the people on this planet and most probably none of them will be wrong. Nelson Mandela, while struggling for freedom has mentioned - "For to be free is not merely to cast off one's chains, but to live in a way that respects and enhances the freedom of others".

If we go deep through this quote, we will find out that it is not only about human freedom, but very much linked to economic freedom as well.

Economic freedom requires empowered individuals. It is a fundamental right of every citizen to control their own property and to make decisions without any coercion of other side. The success of every individual depends on their personal labor and initiative, their effort and ability. Institutions should not discriminate either or in favor of people to any factor unrelated to individual merit, government decision making must be characterized by openness and transparency. The only factor that gives incentives to the allocation of resources for production/consumption can be open competition [1].

The other important thing in this layout is the Government matter. Usually, people see a critical importance of government in their daily activities, but very few realize what should be the main role of government. In an economically free society the role of government is to deal with something

Manuscript received May 20, 2017; revised June 17, 2017.

Vakhtang Chkareuli is with Ivane Javakhishvili Tbilisi State University; Ministry of Finance of Georgia, Georgia (e-mail: vakhtangchkareuli@gmail.com). that market cannot do for itself, namely, to determine, arbitrate and enforce the rules for daily activities of thousands of economic agents. Generally, state action or government control that interferes with individual autonomy, limits economic freedom, but the goal is not simply an absence of government coercion. Just like a good game requires acceptance by the players both of the rules and of the umpire to interpret and enforce them, so a good society requires that its members agree on the general conditions that will manage relations between them [2].

\section{OPtimal LeVEl of ECONOMIC FREEDOM}

Optimal level of "freedom" generally and "economic freedom" in particular is a term of continuous polemics throughout different societies. There is no single, correct answer to the question - What is the optimal level of economic freedom? No one can assume that current score performed by this or that country is the most effective and there is no need of any improvements. Optimal level of economic freedom is not a constant level which can be gained and preserved. It varies from country to country and depends on many different factors such as geopolitical environment, country's traditions, the level of economic development etc.

Daily, there are thousands of economic activities between even more economic agents from different countries, what causes fluctuations and many changes throughout the market. It is clear that, every country needs to accept these daily challenges and adjust their economic policy to benefit [3].

\section{MAIN ASPECTS OF ECONOMIC FREEDOM}

There is no official definition to economic freedom. However, most economists agree that economic freedom includes the freedom to choose and supply resources, competition in business, the right to trade with others and the right to secure property rights rightfully obtained by individuals.

To consider any environment, as an economically free, there should exist political, civil and economic pre-conditions. [3] Non-existence of absolute freedom in a modern world should not give us a reason not to believe in freedom itself.

Generally, there can be discussed a lot of factors which are essential to ensure economic freedom. In this chapter we will discuss most of them and explain their importance throughout economic freedom.

Basically, for ensuring "rational freedom" we need a sound legislative basis, open markets and proper fiscal performance by the government. Let's go deeper through above mentioned and discuss of what do they consist and 
what is extremely essential for economic freedom.

Mostly, individuals can be considered as an economically free when 1) property they acquire without the use of force, fraud or theft is protected from physical invasion by others, and B) they are free to use, exchange, or give their property to another if their actions do not violate the identical rights of others. "Property rights" is the first basic sub-component to legislative basis [4].

In any economy there are two key rules of the game: property right institutions, which include protections against expropriation by the government or any other party, and contracting institutions, which facilitate private contracts between citizens.

The importance of having well-defined and strongly protected property rights is now widely recognized among economists and policymakers. A private property system gives individuals the exclusive right to use their resources as they see fit. This right to rule over what is theirs leads property users to take full account of all the benefits and costs of employing those resources in a particular manner.

Property rights issue is especially actual to the post-soviet countries. Centrally planned economic system, where private property was restricted changed the mindset of generations. This problem stays unsolved in most of transition countries.

The other sub-component is fair judicial system. In its broader sense, justice is action in accordance with the requirements of specific laws. In its narrower sense, justice is fairness. It is action that pays due regard to the proper interests, property, and safety of one's fellows. The principles of justice and fairness can be thought of as rules of "fair play" [4], [5].

A strong judiciary is necessary to ensure the political stability of liberal democracy. An independent judiciary is especially important in preventing political opportunism and personal enrichment not subject to the correct scrutiny.

It should make a sense for citizens that everyone is equally protected by the law and illegal activities will be punished in every specific occasion without any exceptions.

Third sub-component is transparency of governmental institutions and freedom from corruption. Transparency is multifaceted concept that is often conflated with accountability or even corruption, impartiality, and rule of law. We can define it as increased flow of timely and reliable economic, social and political information, which is accessible to all relevant stakeholders. This perspective emphasizes not only the availability of information, but also its reliability and accessibility to a range of potential agents.

The idea behind transparency of governmental institutions in the layout of economic freedom is that institutions should not discriminate either or in favor of individuals to any factor unrelated to individual merit, government decision making must be characterized by openness and transparency and the level of corruption must be insignificant [5].

The second important factor to reach high levels of economic freedom is free market. Mainly, it includes three important sub-factors: trade freedom, investment freedom and financial freedom. Over and over from different parties we hear that markets must be controlled, in other case it will lead to economic disparity and unfair outcomes. It's clear why politicians fear the free market, because at its root they cannot control it. In a true free market, buyers and sellers conduct their businesses without any government regulation, but there is a continuing debate among politicians and economists about how much government regulation is necessary in the economy. Those who want less regulation argue that if you remove government restrictions, the free market will force businesses to protect consumers, provide superior products or services, and create affordable prices for everyone [6].

In this layout Government is inefficient and creates high bureaucracy level that increases the cost of doing business for everyone. Free markets lead us to the following advantages:

\section{- Political and civil freedom;}

\section{- Economic freedom and transparency;}

- Competitive markets;

\section{- Productive allocation of resources;}

The third issue for ensuring economic freedom was proper fiscal performance by the government. Fiscal performance mainly gathers tax burden and government spending (or government size) under itself.

Tax policy is the main source for any government to generate revenues. Shifting tax burden describes the situation where the economic reaction to a tax causes prices and output in the economy to change, thereby shifting part of the burden to others. If a tax is levied on a non-price sensitive good or service (bread, cigarettes etc.) it wouldn't lead to big changes such as for example unemployment growth. An easy way to see how taxes affect output is to look at the GDP equation:

$$
\mathbf{G D P}=\mathbf{C}+\mathbf{I}+\mathbf{G}+\mathbf{N X}
$$

where GDP is gross domestic product, $\mathrm{C}$ is consumption, $\mathrm{I}$ is investments, $\mathrm{G}$ is government spending and $\mathrm{NX}$ is net exports.

Consumption typically equals to two-thirds of GDP. As you would expect, lowering taxes raises disposable income, allowing the consumer to spend additional sums, thereby, increasing GDP.

Reducing taxes, therefore, pushes out aggregate demand curve as consumers demand more goods and services with their higher disposable incomes. Supply side tax cuts are aimed to stimulate capital formation. If successful, the cuts will shift both aggregate demand and aggregate supply because the price level of supply of goods will be reduced, which often leads to an increase in demand for those goods.

It's a common belief that reducing marginal tax rates would spur economic growth, the idea is that lower tax rates will give people more after-tax income that could be used to buy more goods and services [6].

Almost every economist would agree that there are circumstances in which lower levels of government spending would enhance economic growth and other circumstances in which higher levels of government spending would be desirable. If government spending is zero, presumably there will be very little economic growth because enforcing contracts, protecting property, and developing an infrastructure would be very difficult if there were no government at all. In other words, some government spending is necessary for the successful operation of the rule of law. Different studies show that economic activity is very low or nonexistent in the absence of government, but it jumps dramatically as core functions of government are financed. This does not mean that government costs nothing, but that 
the benefits overweigh the costs.

\section{ECONOMIC FREEDOM AND RISING LIVING STANDARDS}

There is an affirmative link between economic freedom and economic development. Countries that allow their citizens more economic freedom achieve higher incomes and better living standards. Freedom, first of all empowers individuals giving them more options and choices. When people have more choices they are more likely to be engaged in entrepreneurial activities, what in turn reflects in creating new jobs and innovative products, growing investment opportunities and refining services [7].

Global world economy has moved towards greater economic freedom over last 20 years, during this period real GDP has increased by 80 percent.

Achieving greater overall prosperity is equally important to the whole world as it lifts hundreds of thousands people out of poverty and diminishes the global poverty rate.

Fig. 1 shows the performance of top five freest economies versus least five freest economies by different regions of the globe in GDP per capita [8], [9].

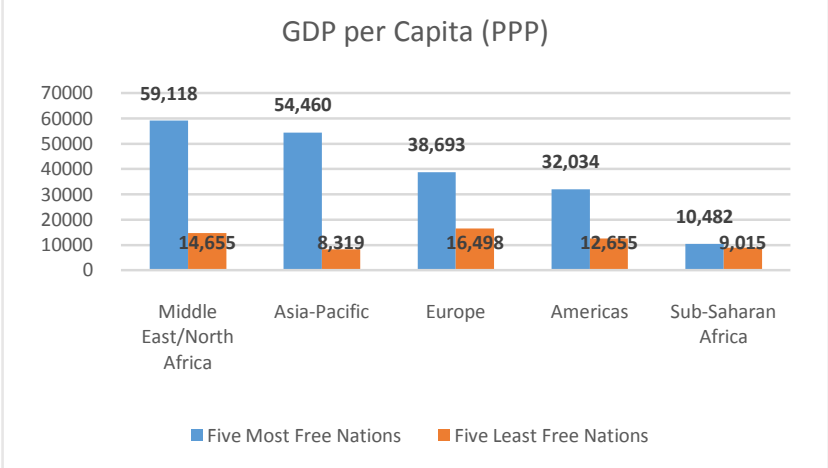

Fig. 1. Countries comparison by GDP per capita (PPP).

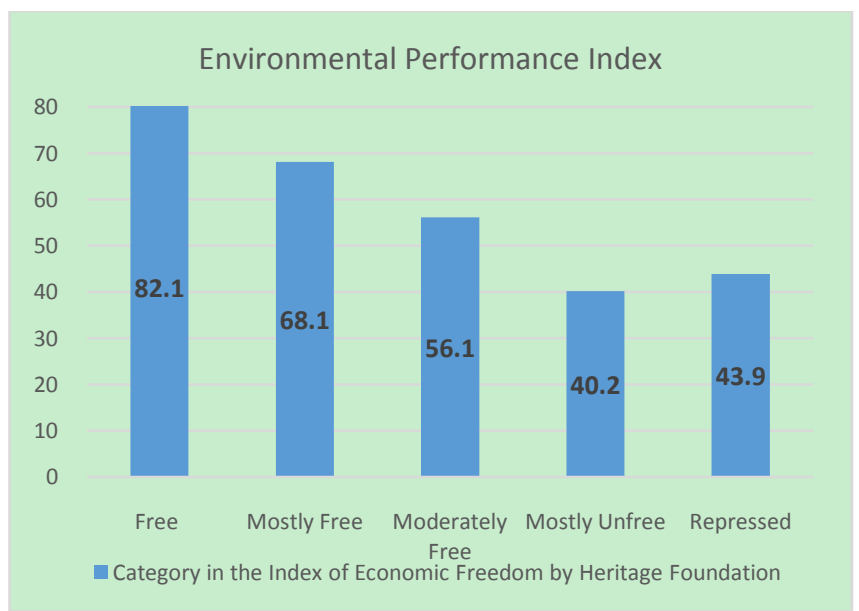

Fig. 2. Environmental performance index by countries from different economic freedom categories.

Apart from growing incomes, economic freedom encourages environmental protection. Over the past decades, the most obvious improvements in clean energy use have occurred more as an advance in technology rather than government regulations. Innovative products and services are always coming from the private sector, not the government. Giving incentives to individuals lead us to the advance in technologies. The positive link between economic freedom and higher levels of innovation ensures greater economic dynamism in coping with various developmental challenges by spurring virtuous cycle of investment, innovation and dynamic entrepreneurial growth [10].

Around the world, economic freedom has shown to increase countries' capacity and their ability to improve overall environmental performance.

Fig. 2 shows how countries from different economic freedom index categories perform in Environmental Performance Index. ${ }^{1}$

\section{CONCLUSION}

One of the most enduring questions in economics is what causes economies to grow. Liberals find that free markets, the protection of private property rights, and a minimal government presence in the economy lead to prosperity, in other words economic freedom leads to economic growth.

Economic freedom fosters incentives and the effectiveness of resource allocation, which in turn reinforces productivity and economic growth.

We divided main aspects of economic freedom into three main directions and discussed their sub-components. Property rights, sound judicial system, government integrity, tax burden, government spending, fiscal health and open markets are most vital for ensuring rational economic freedom in a country.

Still the question about the optimal level of economic freedom stays open. No one can assume that "golden score" is gained and enough, that it does not need any further improvements. The most essential thing for keeping economic freedom at its finest is Government. It has to deal with market imperfectness and offer the "fair play" principles to all. Government should keep economy open and free and not act in ways that distorts it. The only thing that stimulates open competition is freedom of individuals to act as they fit.

Countries that allow private ownership of property by fair and efficient judicial system create incentives to entrepreneurial initiatives in comparison with countries that control economic resources.

The free market system is rooted in the principles of economic freedom.

\section{REFERENCES}

[1] J. Gwartney and R. Lawson, "The concept and measurement of economic freedom," European Journal of Political Economy, pp. 405-430, 2003.

[2] M. Friedman, Capitalism and Freedom, Chicago: The University of Chicago Press, 2002.

[3] R. Holcombe, "Make economics policy relevant. Depose the omniscient benevolent dictator," The Independent Review, pp. 165-176, 2012.

[4] C. Bjornskov, "Economic freedom and economic crises," European Journal of Political Economy, pp. 11-23, 2016.

[5] M. C. Rode, "Economic freedom and growth. Which policies matter the most?" Constitutional Political Economy, pp. 95-133, 2012.

[6] J. Dawson, "Macroeconomic volatility and economic freedom - a preliminary analysis," in Economic Freedom of the World: 2010 Annual Report, J. D. Gwartney, R. A. Lawson, J. Hall Eds. The Fraser Institute, Vancouver, pp. 175-185, 2010.

${ }^{1}$ Economic Freedom Index is calculated annually by Heritage Foundation. It defines five categories of freedom. They are Free, Mostly Free, Moderately Free, Mostly Unfree and Repressed. 
[7] M. Farhadi, R. M. Islam, and S. Moslehi, "Economic freedom and productivity growth in resource-rich economies," World Development, pp. 109-126, 2015.

[8] World Bank. (April 20, 2017). [Online]. Available: http://data.worldbank.org/

[9] The Heritage Foundation. (April 15, 2017). [Online]. Available: http://www.heritage.org/index/explore

[10] L. Pieroni and G. d'Agostino, "Corruption and the effects of economic freedom," European Journal of Political Economy, pp. 54-72, 2013

[11] R. J. Cebula, J. Clark, and F. G. Mixon, "The impact of economic freedom on per capita real GDP: A study of OECD nations," The Journal of Regional Analysis \& Policy, pp. 34-41, 2013.

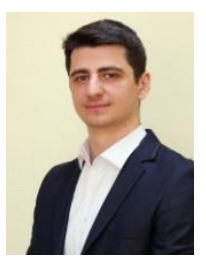

Vakhtang Chkareuli was born in a small town Vladikavkaz (Russian Federation), but grown up in Tbilisi, Georgia. In 2013, Mr. Vakhtang became a bachelor of Business Administration at Tbilisi State University. After graduating he passed for the master's program of economics at the same university (module macroeconomics). Now Mr. Vakhtang is a PhD candidate in economics at Tbilisi State University.
During 2014 to 2016, Mr. Vakhtang Chkareuli was working at Shota Rustaveli National Science Foundation of Georgia, department of scientific grants and programs management, evaluating and analysis.

From the beginning of 2016-till today Mr. Vakhtang is working at the Ministry of Finance of Georgia, public internal control department - central harmonization unit.

Vakhtang Chkareuli has won different scholars for short-term visits on international scientific events, and a $\mathrm{PhD}$ scholar. Also, he is a winner of Dora Plus scholarships for visiting $\mathrm{PhD}$ students at the University of Tartu. Vakhtang Chkareuli is an author of several scientific projects and papers. Research interests: Economic Freedom; Monetary Policy. 